\title{
Effects of Puerariae Radix Extract on Endotoxin Receptors and TNF- $\alpha$ Expression Induced by Gut-Derived Endotoxin in Chronic Alcoholic Liver Injury
}

\author{
Jing-Hua Peng, ${ }^{1,2}$ Tuan Cui, ${ }^{1}$ Zhao-Lin Sun, ${ }^{3}$ Fu Huang, ${ }^{1,2}$ Liang Chen, ${ }^{1,2}$ Lin Xu, ${ }^{1,2}$ \\ Qin Feng, ${ }^{1,2}$ and Yi-Yang $\mathrm{Hu}^{1,2,4}$ \\ ${ }^{1}$ Institute of Liver Diseases, Shuguang Hospital Affiliated to Shanghai University of Traditional Chinese Medicine, \\ Shanghai 201203, China \\ ${ }^{2}$ Key Laboratory of Liver and Kidney Diseases, Ministry of Education, of Shanghai University of \\ Traditional Chinese Medicine, Shanghai 201203, China \\ ${ }^{3}$ Shanghai Institute of Materia Medica, Chinese Academy of Sciences, Shanghai 201203, China \\ ${ }^{4}$ E-Institute of TCM Internal Medicine, Shanghai Municipal Education Commission, Shanghai 201203, China
}

Correspondence should be addressed to Yi-Yang Hu, yyhuliver@163.com

Received 10 July 2012; Revised 10 September 2012; Accepted 10 September 2012

Academic Editor: Gerhard Litscher

Copyright (C) 2012 Jing-Hua Peng et al. This is an open access article distributed under the Creative Commons Attribution License, which permits unrestricted use, distribution, and reproduction in any medium, provided the original work is properly cited.

Kudzu (Pueraria lobata) is one of the earliest medicinal plants used to treat alcohol abuse in traditional Chinese medicine for more than a millennium. However, little is known about its effects on chronic alcoholic liver injury. Therefore, the present study observed the effects of puerariae radix extract (RPE) on chronic alcoholic liver injury as well as Kupffer cells (KCs) activation to release tumor necrosis factor alpha (TNF- $\alpha$ ) induced by gut-derived endotoxin in rats and macrophage cell line. RPE was observed to alleviate the pathological changes and lipids deposition in liver tissues as well as the serum alanine aminotransferase (ALT), aspartate aminotransferase (AST), and hepatic gamma-glutamyl transpeptidase (GGT) activity. Meanwhile, RPE inhibited KCs activation and subsequent hepatic TNF- $\alpha$ expression and downregulated the protein expression of endotoxin receptors, lipopolysaccharide binding protein (LBP), CD14, Toll-like receptor (TLR) 2, and TLR4 in chronic alcohol intake rats. Furthermore, an in vitro study showed that RPE inhibited the expression of TNF- $\alpha$ and endotoxin receptors, CD14 and TLR4, induced by LPS in RAW264.7 cells. In summary, this study demonstrated that RPE mitigated liver damage and lipid deposition induced by chronic alcohol intake in rats, as well as TNF- $\alpha$ release, protein expression of endotoxin receptors in vivo or in vitro.

\section{Introduction}

Alcohol abuse is a public issue and one of the major causes of liver disease worldwide. It covered large proportion of the deaths from liver disease not only in western world [1], but also in the eastern countries. Since 1980s the morbidity and mortality of alcoholic liver disease (ALD) has increased abruptly and presented a more serious trend in recent years in China [2].

ALD encompasses a spectrum of injury, ranging from simple steatosis, hepatitis, and cirrhosis. In alcoholic fatty liver, even the fatty drops disappear on abstinence and steatosis still increase the susceptibility of hepatocyte to further injury [3-7]. The continued ingestion of alcohol results in the subsequent steatohepatitis characterized with neutrophil infiltration, hepatocyte degeneration, ballooning, and oncotic necrosis $[8,9]$ that rarely recover to normal hepatic histology even with ethanol withdrawal [9]. Alcoholic steatohepatitis triggers the pathological progress to fibrosis and then cirrhosis, so as to this stage appears to represent a rate-limiting step in the progression of ALD $[10,11]$. Therefore, blocking or reversing the early-phase histopathologic changes (steatosis and steatohepatitis) is the key strategy of ALD treatment.

Besides alcohol metabolism and oxidant stress, endotoxin, a toxic lipopolysaccharide (LPS) component of the 


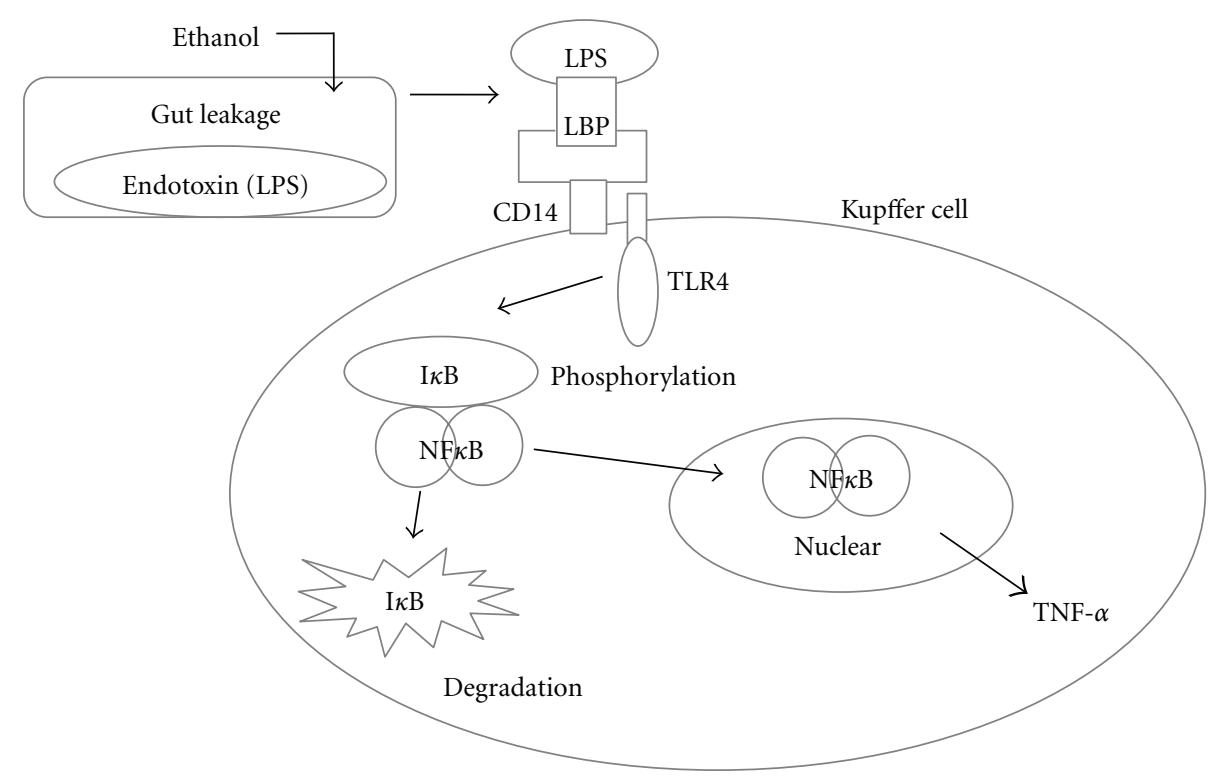

FIGURE 1: Mechanism of Kupffer cells activation releasing TNF- $\alpha$ to promote liver injury induced by gut-derived endotoxin in alcoholic liver disease.

gut Gram-negative bacteria, has also been revealed to be one of the classical mechanisms of alcoholic liver injury $[12,13]$. As a result of increased intestinal permeability caused by alcohol, endotoxin releases into the circulation, transporting in complex of LPS and LPS-binding protein (LBP) and then binds to the CD14 receptor on hepatic Kupffer cells (KCs). The CD14-LBP-LPS complex interacts with toll-like receptor 4 (TLR4) to trigger a signaling cascade in KCs that activates nuclear factor $\kappa \mathrm{B}(\mathrm{NF} \kappa \mathrm{B})$ and promotes the transcription of preinflammatory cytokines, especially tumor necrosis factor alpha (TNF- $\alpha$ ) [14]. TNF- $\alpha$ can itself further increase gut permeability as well as oxidant stress and induces apoptosis and production of other cytokines, perpetuating, and progressing liver injury [15] (Figure 1).

Kudzu (Pueraria lobata) is one of the earliest medicinal plants used to treat alcohol abuse in traditional Chinese medicine for more than a millennium. It has been revealed that antidipsotropic isoflavones isolated from radix puerariae, including puerarin, daidzin, and daidzein, suppressed the ethanol intake of rodents, abolished the development of alcohol withdrawal symptoms [16-23], increased the antioxidant enzymes (such as $\mathrm{Cu} / \mathrm{Zn} \mathrm{SOD}$ and catalase [CAT]), and mitigated the hepatic oxidant injury in ethanoltreated rats [24]. But few investigations on the mechanisms of the radix puerariae extract (RPE) antialcoholic liver injury were conducted comprehensively.

In the present study, we investigated the effects of RPE on chronic alcoholic liver injury in rats as well as the expression of endotoxin receptors and TNF- $\alpha$ induced by gut-derived endotoxin in vivo and in vitro.

\section{Materials and Methods}

2.1. Preparation of PRE. Radix puerariae, the root of Pueraria lobata (Willd) Ohwi (Shanghai Leiyunshang Pharmaceutical
Co. Ltd, Shanghai, China) was powered and extracted with $70 \%$ alcohol for two hours, three times, concentrated with the vacuum rotary evaporator and freeze-dried. The dried powder was then dissolve in distilled water, filtered, and subjected to a macroporous resin D101 column $(11.5 \mathrm{~cm} \times$ $85.5 \mathrm{~cm}$ ), eluting with distilled water and $70 \%$ ethanol. The $70 \%$ ethanol eluting fluid was dried with a rotary evaporator and then stored desiccated in dark at $4^{\circ} \mathrm{C} .3 .89 \mathrm{~g}$ of RPE was obtained from $100 \mathrm{~g}$ of the dried Radix puerariae.

2.2. Analysis of RPE. The standard constituents used for the quantitative analysis of RPE were puerarin, daidzin, and daidzein, which are currently recommended for quality control of radix puerariae. These standards were purchased from Shanghai Win herb Medical Scientific \& Technology Development Co. Ltd (Shanghai, China).

The standard compounds and RPE were dissolved in $30 \%$ ethanol, filtered through $0.2 \mu \mathrm{m}$ nylon filters, and analyzed by HPLC procedures. The HPLC apparatus (Agilent 1200 Series, USA) was employed for analysis. The chromatographic separation was carried out using a mixture of acetonitrile (A) and water containing $0.02 \mathrm{~mol} / \mathrm{ul}$ phosphoric acid (B), and the mobile phase was conducted as Table 1 demonstrating. The column eluent was monitored at UV $250 \mathrm{~nm}$. The chromatography was performed at room temperature with a flow rate of $1.0 \mathrm{~mL} / \mathrm{min}$, and $10 \mu \mathrm{L}$ volume was analyzed.

Analysis showed that $100 \mathrm{mg}$ RPE contained $49.5 \mathrm{mg}$ puerarin, $1.2 \mathrm{mg}$ daidzin, and $0.15 \mathrm{mg}$ daidzein, indicating that puerarin was the major constituent in RPE (Table 1, Figure 2).

2.3. Animals and Treatments. Male Sprague-Dawley (SD) rats $(160 \pm 10 \mathrm{~g})$ were obtained from Shanghai laboratory animal center of Chinese academy of sciences (Shanghai, 


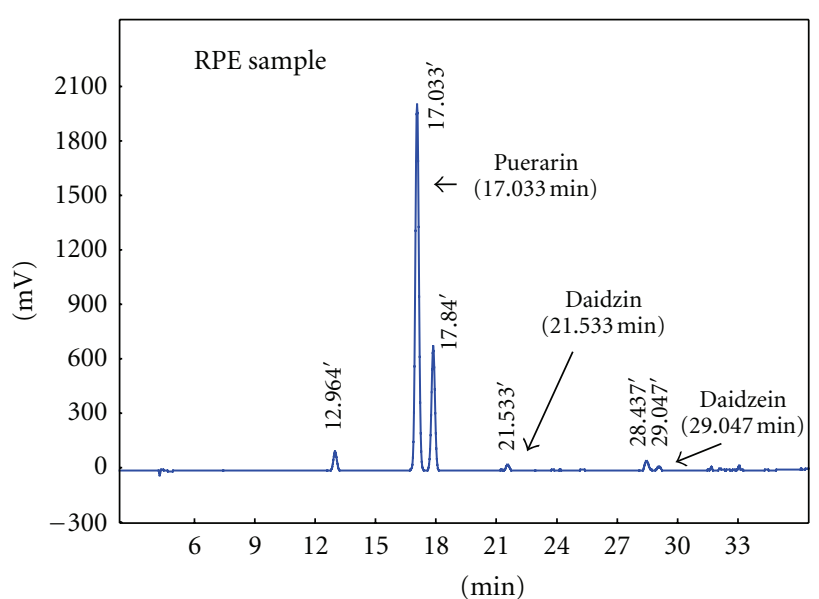

(a)

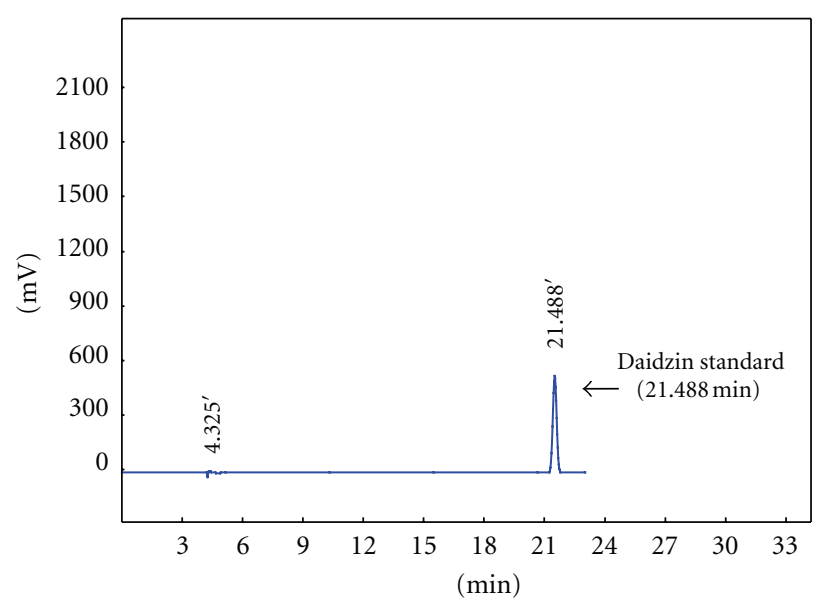

(c)

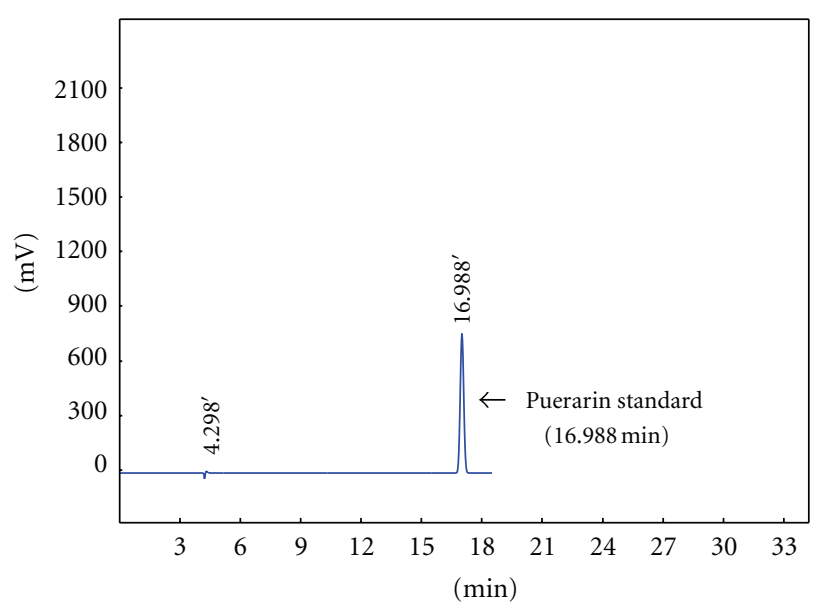

(b)

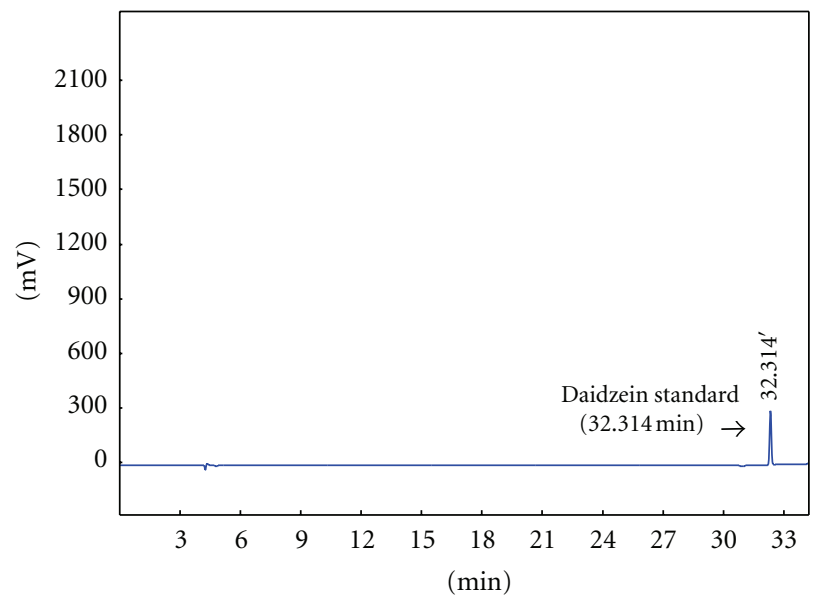

(d)

FIGURE 2: HPLC chromatograms of the RPE and the standard compounds: (a) RPE, (b) puerarin standard (16.988 min), (c) Daidzin standard (21.488 $\mathrm{min})$, and (d) daidzein (32.314 $\mathrm{min})$.

TABLE 1: HPLC mobile phase gradient.

\begin{tabular}{lcc}
\hline Time $(\mathrm{min})$ & Moble A (\%) & Mobile B (\%) \\
\hline 0.00 & 15 & 85 \\
25.00 & 35 & 65 \\
30 & 100 & 0 \\
35 & 100 & 0 \\
\hline
\end{tabular}

China) and acclimatized for 7 days after delivery. All rats were maintained on a reverse $12 \mathrm{~h}$ light: $12 \mathrm{~h}$ dark cycle. Animal handling and procedures were performed according to international guidelines for the use and care of laboratory animals. The experimental protocol was approved by the local ethics committee.

Rats were divided into four groups: control ( $n=$ $10)$, ethanol $(n=10)$, ethanol plus high-dosage RPE $(240 \mathrm{mg} / \mathrm{kg} \cdot \mathrm{d}, n=10)$, and ethanol plus low-dosage $\mathrm{RPE}(120 \mathrm{mg} / \mathrm{kg} \cdot \mathrm{d}, n=10)$ group. Lieber-DeCarli control and ethanol liquid diet were prepared according to the prescription of Lieber-DeCarli diet [25] as described in the previous research [26]. Rats in control group ingested Lieber-DeCarli control liquid diet and rats in ethanol or drug-administrated group ingested Lieber-DeCarli alcohol liquid diet. Ethanol provided 36\% energy in the alcohol liquid diet, which was substituted by dextrin-maltose in the control liquid diet. One liter liquid diet contains $1000 \mathrm{Kcal}$ energy. Reagents in the Liber-DeCarli formula were purchased from Sinopharm Chemical Reagent Co., Ltd (Shanghai, China). Rats were single-cage rearing and liquid diet was intake freely without additional water or chow for eight weeks. At the beginning of the third week, rats in ethanol plus high- and low-dosage RPE groups were administrated with RPE by gavage in $240 \mathrm{mg} / \mathrm{kg} \cdot \mathrm{d}$ and $120 \mathrm{mg} / \mathrm{kg} \cdot \mathrm{d}$, respectively, the others with equal volume of sterile water. At the end of the eighth week, rats were anaesthetized with nembutal $(45 \mathrm{mg} / \mathrm{kg}$, i.p.); liver tissue and serum were collected and stored in $-80^{\circ} \mathrm{C}$ for histological, biochemical, and Western blot analysis. Two milliliter blood from portal vein was collected in pyrogen-free and heparin-pretreated tube for endotoxin detection. 
2.4. Cell Culture and Treatment. The murine macrophage cell line, RAW264.7 cells, (Shanghai Institutes for Biological Sciences, Chinese Academy of Sciences, Shanghai, China) were cultured in RPMI-1640 (GIBCO Invitrogen Corporation, CA, USA) containing 10\% fetal bovine serum (FBS) (GIBCO) in $5 \% \mathrm{CO}_{2}$ incubator (Heraeus Holding $\mathrm{GmbH}$, Germany) at $37^{\circ} \mathrm{C}$. Cultured for $24-48 \mathrm{~h}$, approximately $70 \%$ confluence, RAW264.7 cells were divided into five groups: control, LPS, $0.84 \mathrm{mg} / \mathrm{L}$ RPE (containing $1 \mathrm{nM}$ puerarin) plus LPS, and $8.4 \mathrm{mg} / \mathrm{L}$ (containing $10 \mathrm{nM}$ puerarin) $\mathrm{RPE}$ plus LPS group. RPE was dissolved in dimethyl sulfoxide (DMSO) and diluted with RPMI-1640 (final concentration of DMSO was $0.005 \%$ ) . After preincubated with RPE for $4 \mathrm{~h}$, the cells were treated with LPS (Escherichia coli 0111 : B4, Sigma-Aldrich Co., USA) $0.1 \mu \mathrm{g} / \mathrm{mL}$ for $2 \mathrm{~h}$ without rinse. And then the supernatant and cellular proteins were collected for assay.

2.5. LDH Secretion Test in RAW264.7. RAW264.7 cells were cultured with 10\% FBS RPMI-1640 (control), 84 mg/L RPE (containing $100 \mathrm{nM}$ puerarin) plus 10\% FBS RPMI-1640, $840 \mathrm{mg} / \mathrm{L}$ RPE (containing $1 \mu \mathrm{M}$ puerarin) plus 10\% FBS RPMI-1640, and $8.4 \mathrm{~g} / \mathrm{L}$ RPE (containing $10 \mu \mathrm{M}$ puerarin) plus 10\% FBS RPMI-1640, respectively. After 6 hours, the activity of lactate dehydrogenase (LDH) in the supernatant was detected. The LDH activity was corrected with the cellular protein concentration in every dish and expressed as $\mathrm{U} / \mathrm{pg}$ proteins.

2.6. Histological Examination. Liver tissue was formalinfixed and embedded in paraffin. Sections ( $4 \mu \mathrm{m}$ thick) were stained with hematoxylin-eosin (H.E.) (Nanjing Jiancheng Bioengineering institute, Nanjing, China) and examined under light microscope (Olympus Medical Systems Corp., Tokyo, Japan).

Frozen hepatic tissue ( $7 \mu \mathrm{m}$ thick) embedded in optimum cutting temperature (OCT) compound (Sakura Finetek USA, Inc., CA, USA) was stained with oil red O (Sinopharm Chemical Reagent Co., Ltd, Shanghai, China) for hepatic lipid observation (Olympus Medical Systems Corp., Tokyo, Japan).

2.7. Serum ALT and AST Assay. Activity of alanine aminotransferase (ALT), aspartate aminotransferase (AST) in serum was determined with the corresponding biochemical assay kits (Nanjing Jiancheng Bioengineering institute, Nanjing, China).

2.8. Hepatic GGT Assay. Liver tissue (100 mg) was homogenized in $1 \mathrm{~mL} 0.9 \% \mathrm{NaCl}$. The homogenate was centrifuged at $1,000 \mathrm{~g}, 4^{\circ} \mathrm{C}$ for $15 \mathrm{~min}$, the supernatant was removed into clean tubes and centrifuging at 3,000 g for $10 \mathrm{~min}$, avoiding the upper adipose and removing the transparent for gammaglutamyl transpeptidase (GGT) assay (Nanjing Jiancheng Bioengineering institute, Nanjing, China).

2.9. Hepatic TG Assay. Liver tissue (200 mg) was homogenized in $3 \mathrm{~mL}$ ethanol-acetone mixture (1:1 in volume).
The total hepatic triglyceride (TG) extracted in the medium at $4^{\circ} \mathrm{C}$ overnight and then, centrifuged at $1,000 \mathrm{~g}, 4^{\circ} \mathrm{C}$ for $20 \mathrm{~min}$, the supernatant was removed for TG assay with TG analysis kits (Dongou Bioengineering Co. Ltd, Zhejiang, China).

2.10. Endotoxin Assay in Plasma from Portal Vein. Blood collected from portal vein was centrifuged at $500 \mathrm{~g}, 4^{\circ} \mathrm{C}$ for $15 \mathrm{~min}$, plasma was removed immediately for analysis, according to the instruction of Pyrochrome limulus amebocyte lysate (LAL) kit (Cat NO. C1500, Associates of Cape Cod, Inc., TX, USA).

2.11. Immunohistochemical Assessment of Hepatic CD68. As discribed in previous study [27], $4 \mu \mathrm{m}$ thick paraffin sections were used for immunohistochemical assessment. Briefly, after endogenous peroxidase blockage and bovine serum albumin blockage, the samples were incubated at $4^{\circ} \mathrm{C}$ overnight, with a $1: 100$ dilution of anti-CD68 primary antibody (monoclonal anti-rat CD68, AbD Serotec, NC, USA). Following the processing of the samples incubated with a 1:250 dilution of horseradish-peroxidase-(HRP-) linked goat anti-mouse IgG (sc-2031, Santa Cruz Biotechnology Inc. Santa Cruz, CA) for $1 \mathrm{~h}$ at $37^{\circ} \mathrm{C}$, diamino benzidine (DAB) was applied as a chromogen and hematoxylin was used for floor staining.

2.12. Measurement of TNF- $\alpha$ Level by ELISA. Liver TNF$\alpha$ was isolated as described in previous research [28], liver pieces $(1.0 \mathrm{~g})$ were minced thoroughly in ice-cold radioimmunoprecipitation assay buffer $(150 \mathrm{mM} \mathrm{NaCl}, 5 \mathrm{mM}$ EDTA, $50 \mathrm{mM}$ Tris base, $0.3 \%$ Triton $\mathrm{X}-100,0.03 \%$ sodium dodecyl sulfate, $0.3 \% \mathrm{Na}$-deoxycholate, and $1 \%$ protease inhibitor cocktail, $\mathrm{pH}$ 7.4) and lysised on ice for $30 \mathrm{~min}$. The liver tissue extracts were then centrifuged at $15,000 \mathrm{~g}$ for $20 \mathrm{~min}$ at $4^{\circ} \mathrm{C}$. Removing the supernatants to clean tubes and centrifuging again at $15,000 \mathrm{~g}$ for $20 \mathrm{~min}$ at $4^{\circ} \mathrm{C}$, the supernatants of this spin were then used for enzyme-linked immunosorbent assay (ELISA). TNF- $\alpha$ in both hepatic tissue and the culture supernate of RAW364.7 cell was determined by a commercially available ELISA kit (Cat. NO. KRC3012, Invitrogen Corporation, Camarillo, CA, USA) according to the manufacturer's instruction. The result was corrected by protein concentration (bicinchoninic acid [BCA] protein concentration assay kit, Beyotime Inst. Biotechnology, Jiangsu, China).

2.13. Determination of CD68 and Endotoxin Receptors in Liver Tissue by Western Blot. As described previously [27, 29], total proteins in liver tissue and cell layers were extracted, analyzed with BCA protein concentration assay kit (Beyotime Inst. Biotechnology, Jiangsu, China).

Sample protein was separated by electrophoresis in 10\% SDS-PAGE separating gel with Bio-Rad electrophoresis system (BioRad Laboratories, Hercules, CA, USA). The primary antibodies (mouse anti-rat glyceraldehydes-3phosphate dehydrogenase, GAPDH antibody, 1:5000 dilution, KANGCHEN Bio-Tech Inc., Shanghai, China; mouse 
TABLE 2: Liquid diets intake, body weight, and liver/body weight ratio.

\begin{tabular}{lccc}
\hline Group $(n)$ & Volume of liquid diet intake $(\mathrm{mL})$ & Body weight $(\mathrm{g})$ & $\begin{array}{c}\text { Liver/body weight ratio } \\
\text { (g/kg body weight) }\end{array}$ \\
\hline Control $(10)$ & $2726 \pm 75$ & $262 \pm 28$ & $20.06 \pm 2.99$ \\
Ethanol $(10)$ & $2707 \pm 218$ & $257 \pm 50$ & $28.07 \pm 5.70^{* *}$ \\
$240 \mathrm{mg} / \mathrm{kg} \cdot \mathrm{d}$ RPE $(10)$ & $2723 \pm 166$ & $269 \pm 22$ & $31.17 \pm 4.09$ \\
$120 \mathrm{mg} / \mathrm{kg} \cdot \mathrm{d}$ RPE $(10)$ & $2726 \pm 141$ & $276 \pm 24$ & $29.45 \pm 4.61$ \\
\hline
\end{tabular}

${ }^{* *} P<0.01$, versus control.

anti-rat CD68 antibody, 1:100 dilution, AbD Serotec, NC, USA; mouse anti-rat CD14 antibody, 1:200 dilution, Santa Cruz biotechnology Inc., CA, USA; goat anti-rat LBP antibody, 1:100 dilution, Santa Cruz biotechnology Inc., CA, USA; rabbit anti-rat TLR2 antibody, 1:2000 dilution, Epitomics, Inc. CA, USA; rabbit anti-rat TLR4 antibody, 1:200 dilution, Santa Cruz biotechnology Inc., CA, USA) were incubated at $4^{\circ} \mathrm{C}$ overnight. The corresponding HRPconjugated secondary antibodies (goat anti-mouse IgG, goat anti rabbit-IgG peroxidase linked antibody, 1:5000 dilution, Santa Cruz Biotechnology Inc., CA, USA; rabbit anti-goat-IgG, peroxidase linked antibody, 1:5000 dilution, Jackson ImmunoResearch Laboratories Inc., PA, USA) were incubated at room temperature for $1 \mathrm{~h}$. The ECL kit (Pierce Biotechnology Inc., Rockford, USA) and the Furi FR-980 image analysis system (Shanghai Furi Co., Shanghai, China) were employed for revealing and quantitative analysis of the blots. GAPDH protein was used as the internal control.

2.14. Statistical Analysis. All results were expressed as mean \pm SD. The data were analyzed using a one-way analysis of variance (ANOVA) followed by the least significant difference (LSD) post hoc test. T-test is employed for the comparison of two parameters. Differences were considered statistically significant if the $P$ value $<0.05$.

\section{Results}

3.1. Liquid Diets Intake, Body Weight, and Liver/Body Weight Ratio. At the end of the eighth week, the total volume of liquid diets and the average body weight was no significantly different in various groups $(P>0.05)$. The liver/body weight ratio of rats fed with ethanol liquid diets increased significantly compared with that of rats in control group $(P<0.01)$, and there is no significance statistically between RPE groups and ethanol group (Table 2).

\subsection{Effects of RPE on Live Injury Induced by Chronic Alcohol} Intake. Chronic alcoholic liver injury was examined by biomarkers of liver damage and histological changes in liver tissue. The serum ALT and AST activities significantly increased in ethanol group compared with that in the control (ALT: $124.02 \pm 41.68 \mathrm{U} / \mathrm{L}$ versus $21.81 \pm 7.90 \mathrm{U} / \mathrm{L}, P<$ 0.01 ; AST: $81.25 \pm 30.16 \mathrm{U} / \mathrm{L}$ versus $26.70 \pm 7.99 \mathrm{U} / \mathrm{L}$, $P<0.01)$. The serum ALT of rats in administration with high-dosage RPE group was obviously decreased (87.26 \pm $31.37 \mathrm{U} / \mathrm{L}$ versus $124.02 \pm 41.68 \mathrm{U} / \mathrm{L}, P<0.05)$. The activity of serum AST in high-dosage RPE group demonstrated similar trends $(53.51 \pm 19.16 \mathrm{U} / \mathrm{L}$ versus $81.25 \pm 30.16 \mathrm{U} / \mathrm{L}$, $P<0.05)$. Decrease of these two biomarkers in low-dosage RPE group did not appear statistically significance (ALT: $92.58 \pm 32.14 \mathrm{U} / \mathrm{L}$ versus $124.02 \pm 41.68 \mathrm{U} / \mathrm{L}, P>0.05$; AST: $69.33 \pm 23.72 \mathrm{U} / \mathrm{L}$ versus $81.25 \pm 30.16 \mathrm{U} / \mathrm{L}, P>0.05$ ). On the other hand, hepatic GGT activity increased after ethanol liquid diet intake obviously $(49.75 \pm 3.97 \mathrm{U} / \mu \mathrm{g}$ pro. versus $10.83 \pm 2.11 \mathrm{U} / \mu$ g pro., $P<0.01$ ), and after RPE administration, hepatic GGT activity decreased significantly $(14.71 \pm 2.90 \mathrm{U} / \mu \mathrm{g}$ pro. versus $49.75 \pm 3.97 \mathrm{U} / \mu \mathrm{g}$ pro., $P<$ $0.01 ; 15.63 \pm 2.19 \mathrm{U} / \mu \mathrm{g}$ pro. versus $49.75 \pm 3.97 \mathrm{U} / \mu \mathrm{g}$ pro., $P<0.01$ ) (Figure 3(c)).

After chronic alcohol intake for eight weeks, the macrovesicular steatosis was observed in the most region of lobule, predominantly in centrilobular regions. Lipid vacuoles occupied much of the hepatocyte cytoplasm, and the nucleus and other organelles were pushed to the periphery of the cell. Some hepatocytes appeared bloated, with a wispy, rarefied cytoplasm. The inflammatory cells, such as neutrophil and lymphocytes, scattered located in the pericellular region. RPE of high-dosage or low-dosage treatment alleviated the pathological changes mentioned above (Figure 3(a)).

3.3. Effects of RPE on Hepatic Lipid Deposition. The concentration of TG in liver tissue and oil red $\mathrm{O}$ staining of liver tissue section were employed to demonstrate the hepatic lipid deposition.

The total TG extracted by liver tissue homogenization was tested. As expected, chronic alcohol exposure elicited almost 5-fold increase in hepatic TG levels as compared with control animals $(103.53 \pm 13.59 \mathrm{mg} / \mathrm{g}$ liver tissue versus $22.39 \pm 9.19 \mathrm{mg} / \mathrm{g}$ liver tissue, $P<0.01$ ). The levels of hepatic TG decreased remarkably in RPE-treated animals (high-dosage RPE, $72.90 \pm 24.15 \mathrm{mg} / \mathrm{g}$ liver tissue versus $103.53 \pm 13.59 \mathrm{mg} / \mathrm{g}$ liver tissue, $P<0.01$; low-dosage RPE, $95.64 \pm 9.41 \mathrm{mg} / \mathrm{g}$ liver tissue versus $103.53 \pm 13.59 \mathrm{mg} / \mathrm{g}$ liver tissue, $P<0.05$ ) (Figure 3(c)).

Oil red $\mathrm{O}$ staining slides showed that in the hepatocytes cytoplasm of chronic drinking rats, there were large droplets colored with oil red $\mathrm{O}$, which were widespread distributed in the hepatic lobule, indicating severe steatosis in alcohol intake animals. In animals treated with RPE in high or low-dosage, the droplets were smaller and limited, which indicated that hepatic steatosis was mitigated with RPE administration (Figure 3(b)). 


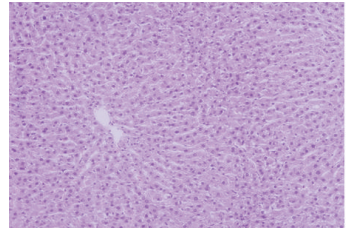

Control

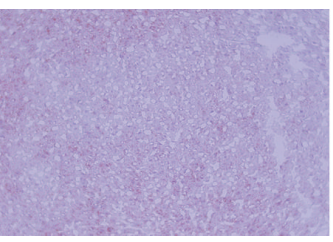

Control

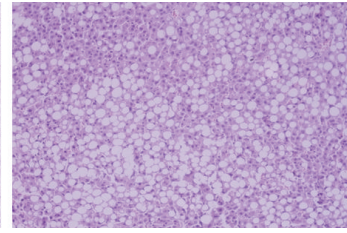

Ethanol

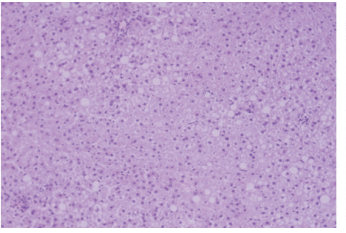

$240 \mathrm{mg} / \mathrm{kg} . \mathrm{d}$

(a)

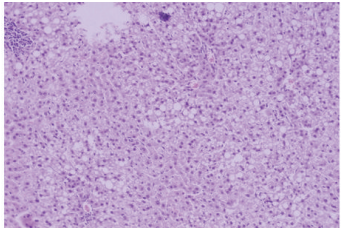

$120 \mathrm{mg} / \mathrm{kg} . \mathrm{d}$

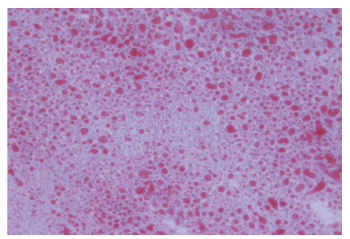

$120 \mathrm{mg} / \mathrm{kg} . \mathrm{d}$

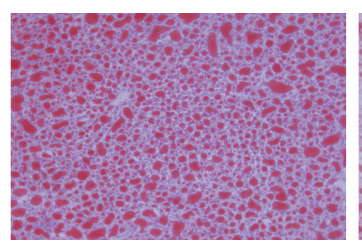

Ethanol

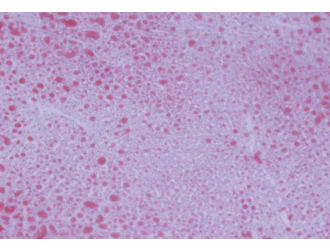

$240 \mathrm{mg} / \mathrm{kg} . \mathrm{d}$

(b)
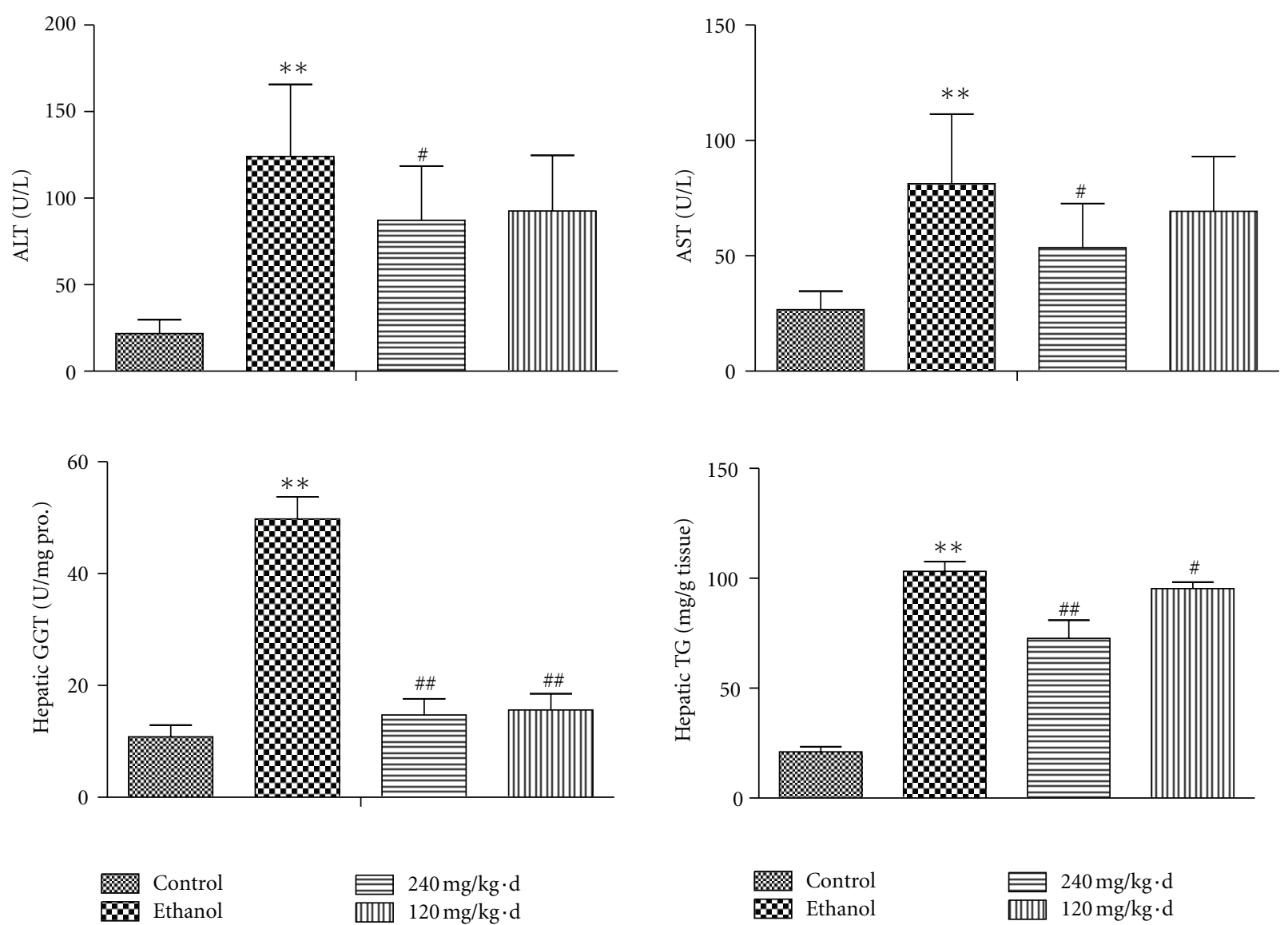

(c)

FIGURE 3: Effects of RPE on liver injury and lipid deposition induced by Lieber-DeCarli diet. (a) Histological observation on the H.E. sections (original magnification, $\times 200$ ). (b) Hepatic lipid droplets observation on red O staining sections (original magnification, $\times 200$ ). (c) Serum ALT, AST, hepatic GGT, and TG variation. Values represent the mean \pm SD of 10 rats. ${ }^{*} P<0.05$, versus control; ${ }^{\#} P<0.05$, versus ethanol; ${ }^{* *} P<0.01$, versus control, ${ }^{\# \#} P<0.01$, versus ethanol.

3.4. Endotoxin Level in the Portal Vein and Hepatic TNF$\alpha$ Concentration. Endotoxin level in the portal vein reflects the situation of endotoxin leakage from gut and indicates the permeability of intestinal wall, indirectly. In the present study, the endotoxin level in the portal vein was found increasingly remarkably after long-term ethanol intake $(0.538 \pm 0.09 \mathrm{EU} / \mathrm{mL}$ versus $0.367 \pm 0.052 \mathrm{EU} / \mathrm{mL}, P<$ 0.05 ); however, not varying after RPE administration (highdosage RPE versus ethanol, $0.547 \pm 0.12 \mathrm{EU} / \mathrm{mL}$ versus 0.538 $\pm 0.09 \mathrm{EU} / \mathrm{mL}, P>0.05$, low-dosage RPE versus ethanol, 

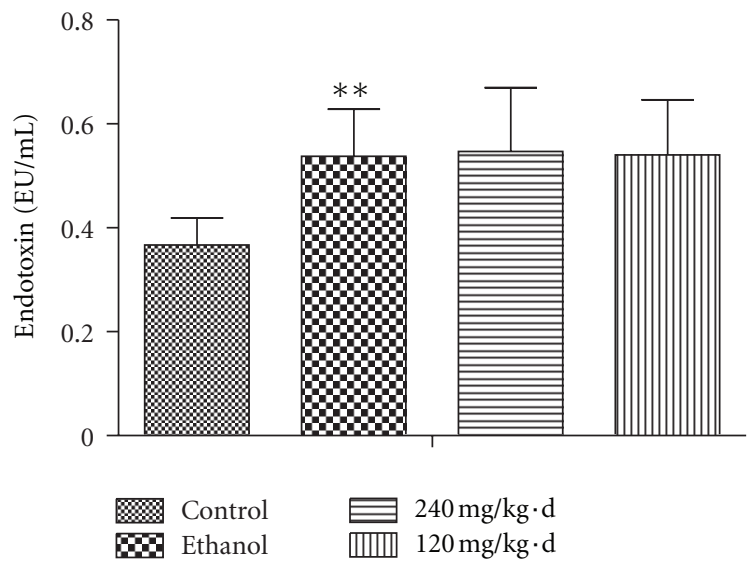

(a)

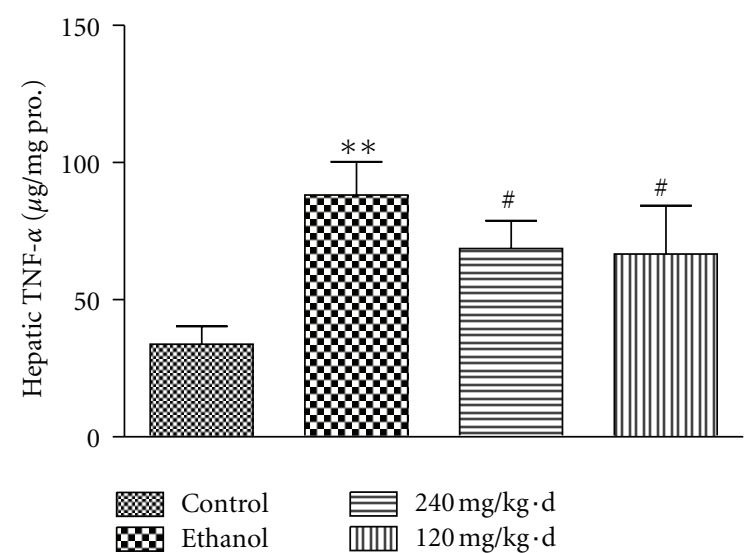

(b)

FIGURE 4: Effects of RPE on endotoxin in the portal vein and hepatic TNF- $\alpha$ concentration. (a) Endotoxin level in portal vein, (b) TNF- $\alpha$ concentration in liver tissue. Values represent the mean \pm SD of 10 rats. ${ }^{* *} P<0.01$, versus control, ${ }^{\#} P<0.05$, versus ethanol.

$0.54 \pm 0.11 \mathrm{EU} / \mathrm{mL}$ versus $0.538 \pm 0.09 \mathrm{EU} / \mathrm{mL}, P>0.05)$ (Figure 4(a)). This result suggested that chronic alcohol exposure promoted endotoxin leakage from intestine, which was not inhibited by RPE administration.

After entering circulation, the gut-derived endotoxin activates Kupffer cells to release preinflammatory factors, such as TNF- $\alpha$, promoting liver injury. In the present study, hepatic TNF- $\alpha$ was detected and it was observed that hepatic TNF- $\alpha$ concentration increased significantly in ethanol group $(88.18 \pm 12.08 \mu \mathrm{g} / \mathrm{mg}$ pro. versus $33.76 \pm$ $6.50 \mu \mathrm{g} / \mathrm{mg}$ pro., $P<0.05)$, and with RPE administration, it decreased obviously $(68.64 \pm 10.19 \mu \mathrm{g} / \mathrm{mg}$ pro. versus $88.18 \pm 12.08 \mu \mathrm{g} / \mathrm{mg}$ pro., $P<0.05 ; 66.70 \pm 17.66 \mu \mathrm{g} / \mathrm{mg}$ pro. versus $88.18 \pm 12.08 \mu \mathrm{g} / \mathrm{mg}$ pro., $P<0.05)$, which is inconsistent with the RPE effects on endotoxin level in portal vein (Figure 4(b)).

3.5. Effects of RPE on Kupffer Cells Activation and Protein Expression of Endotoxin Receptors in Liver. Since no obvious inhibitory effect of RPE on endotoxin leakage from gut

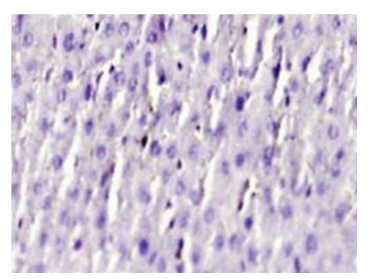

Control

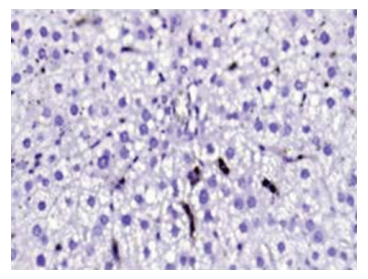

$240 \mathrm{mg} / \mathrm{kg} \cdot \mathrm{d}$

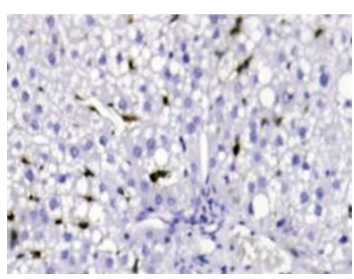

Ethanol

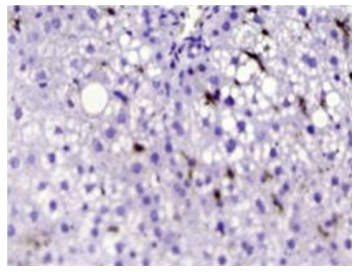

$120 \mathrm{mg} / \mathrm{kg} \cdot \mathrm{d}$ (a)

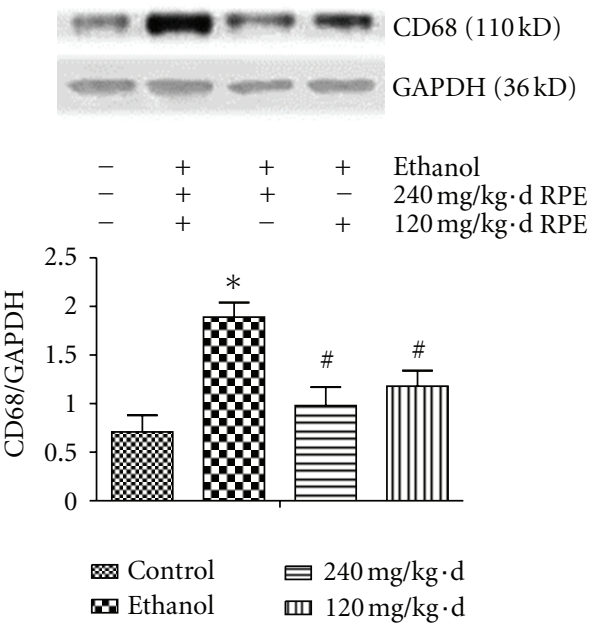

(b)

FIgURE 5: Effects of RPE on Kupffer cells activation in liver. (a) Hepatic CD68 expression detected with immunohistology (original magnification, $\times 400$ ), (b) Hepatic CD68 expression detected with western-blot. Values represent the mean \pm SD of three independent experiments. ${ }^{*} P<0.05$, versus control; ${ }^{\#} P<0.05$, versus ethanol.

was observed, the effect of RPE on KCs activation and endotoxin receptors protein expression were then detected for investigating the mechanism of RPE block TNF- $\alpha$ release.

CD68/macrosialin, a transmembrane protein expressed by activated tissue macrophages [30], was detected as a marker of the activated KCs. Immunohistological assay showed that few CD68-positive staining was observed in the hepatic sinusoidal of control rats (Figure 5(a)). The positive staining in hepatic tissue was stronger and the areas were enlarged in the livers of ethanol-diet raised rats (Figure 5(a)). While CD68 expression decreased in the liver sections of RPE high- or low-dosage administrated rats, respectively (Figure 5(a)), these results were confirmed by westernblotting assay (Figure 5(b)).

LBP, the essential protein for LPS-transferring in the circulation, is predominantly produced by liver [31], which 


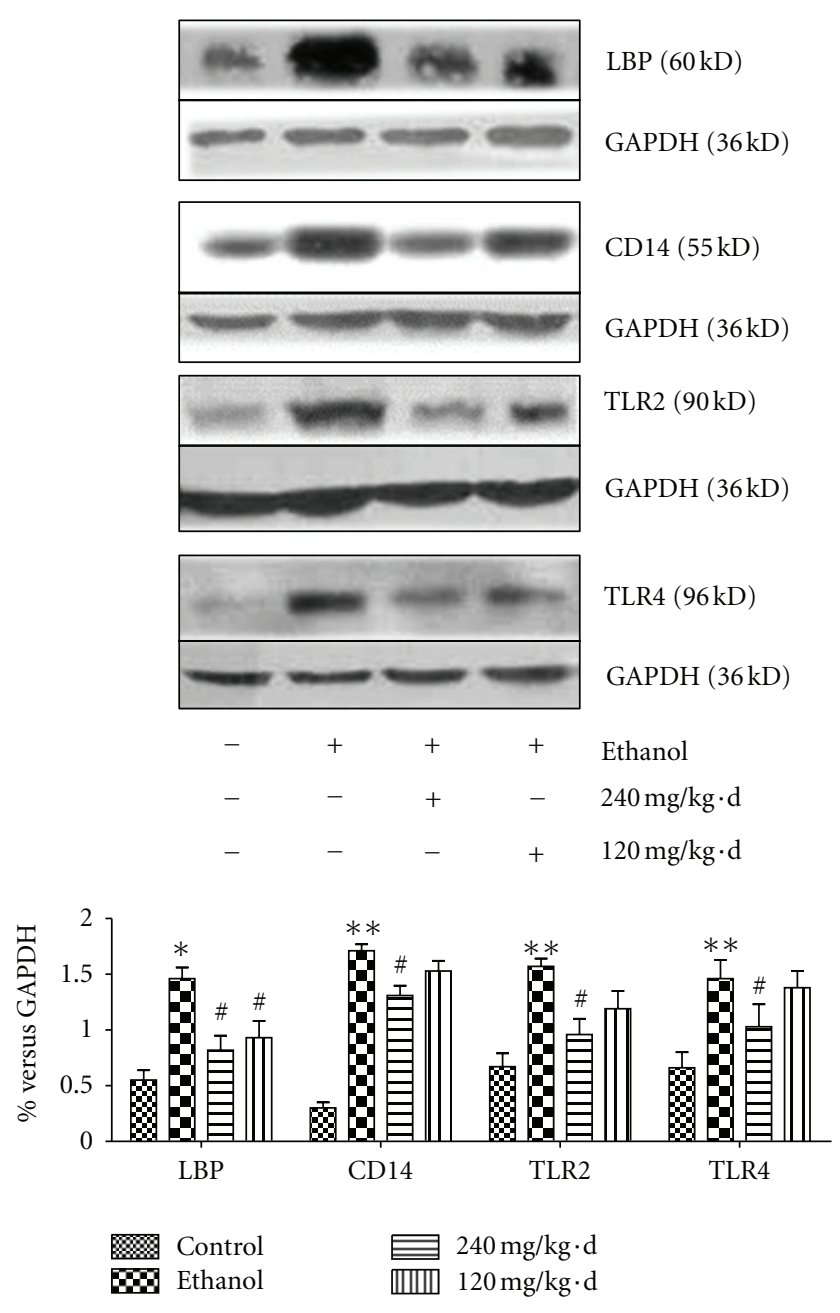

FIGURE 6: Effects of RPE on protein expression of endotoxin receptors in liver. RPE inhibited protein of endotoxin receptors, LBP, CD14, TLR4, and TLR2 (western-blot). Values represent the mean $\pm \mathrm{SD}$ of three independent experiments. ${ }^{*} P<0.05$, versus control; ${ }^{* *} P<0.01$, versus control; ${ }^{\#} P<0.05$, versus ethanol.

binds to LPS of Gram-negative bacteria with high affinity to form the LPS-LBP complex and transfer of LPS to the surface receptors on target cells (KCs), such as membrane CD14. The pattern recognition receptors, TLRs, recognize the signal of LPS delivered by LBP and CD14 and activate the downstream cascades. As been disclosed in protein expression assay, in ethanol-diet group, the protein expression of endotoxin receptors in liver tissue, such as LBP, CD14, TLR4, and TLR2, were increased remarkably compared to that in control group. While administrated with RPE, the protein expression of endotoxin receptors were downregulated significantly, especially, in the high-dosage group (Figure 6).

The results obtained from in vivo study suggested that RPE mitigated alcoholic liver injury and hepatic lipid deposition induced by Lieber-DeCarli diet in rats as well as TNF- $\alpha$ release, protein expression of endotoxin receptors, and KCs activation in liver. Since the endotoxin level in portal vein did not vary between ethanol and RPE groups,
RPE was not indicated probably to inhibit endotoxin leakage from intestinal induced by long-term ethanol exposure. To confirm the direct effects of RPE on TNF- $\alpha$ and endotoxin receptors expression in KCs induced by LPS, the macrophage cell line, RAW264.7, was employed in the subsequent experiments in vitro.

3.6. Activity of LDH in RAW264.7 Supernatant Cultured with Different Concentrations of RPE. The LDH test in RAW264.7 was employed to determine the security range of RPE dosage on cells in vitro. Increase of LDH indicates cell injury and the toxicity of drug.

The toxicity of RPE concentration range of $84 \mathrm{mg} / \mathrm{L}$ (containing $100 \mathrm{nM}$ puerarin), $840 \mathrm{mg} / \mathrm{L}$ (containing $1 \mu \mathrm{M}$ puerarin), and $8.4 \mathrm{~g} / \mathrm{L}$ (containing $10 \mu \mathrm{M}$ puerarin) on RAW264.7 was examined by LDH activity assay in the culture supernatant. After cultured for $6 \mathrm{~h}$, as dosage of RPE increased $(84 \mathrm{mg} / \mathrm{L}, 840 \mathrm{mg} / \mathrm{L}, 8.4 \mathrm{~g} / \mathrm{L})$, LDH activity did not increase comparing to that in control and even decreased in the $84 \mathrm{mg} / \mathrm{L}$ RPE group. That indicated that RAW264.7 cells cultured with $8.4 \mathrm{~g} / \mathrm{L}$ RPE or lower concentration was secure (Table 3).

3.7. Effect of RPE on TNF- $\alpha$ Secretion in RAW264.7 Cell Culture Supernatant Induced by LPS In Vitro. The results showed that TNF- $\alpha$ secretion in the supernatant increased significantly (LPS versus control, $1397 \pm 620 \mathrm{pg} / \mathrm{pg}$ pro. versus $29 \pm 11 \mathrm{pg} / \mathrm{pg}$ pro., $P<0.01)$. Treatment with $0.84 \mathrm{mg} / \mathrm{L}$ (containing $1 \mathrm{nM}$ puerarin) and $8.4 \mathrm{mg} / \mathrm{L}$ (containing $10 \mathrm{nM}$ puerarin) RPE (pretreated for $4 \mathrm{~h}$ and then coincubated with LPS for $2 \mathrm{~h}$ ) reduced the TNF- $\alpha$ secretion induced by LPS $(0.84 \mathrm{mg} / \mathrm{L}$ RPE versus LPS, $594 \pm 391 \mathrm{pg} / \mathrm{pg}$ pro. versus 1397 $\pm 620 \mathrm{pg} / \mathrm{pg}$ pro., $P<0.01 ; 8.4 \mathrm{mg} / \mathrm{L}$ RPE versus LPS, $733 \pm$ $288 \mathrm{pg} / \mathrm{pg}$ pro. versus $1397 \pm 620 \mathrm{pg} / \mathrm{pg}$ pro., $P<0.01)$. No dosage-dependent effects were observed (Figure 7).

3.8. Effect of RPE on Endotoxin Receptors Protein Expression Induced by LPS In Vitro. The protein expression of endotoxin receptors, CD14 and TLR4 in RAW264.7 cells, was upregulated significantly after stimulated by LPS. Similarly, with treatment by $0.84 \mathrm{mg} / \mathrm{L}$ and $8.4 \mathrm{mg} / \mathrm{L}$ RPE (pretreated for $4 \mathrm{~h}$ and then coincubated with LPS for $2 \mathrm{~h}$ ), CD14 and TLR4 protein expressions were downregulated without dosage-dependent effect (Figure 8).

\section{Discussion}

Kudzu (Pueraria lobata) has been used in China as an anti-inebriation agent for centuries. Puerarin, daidzin, and daidzein have been identified as the three major isoflavonoid compounds in RPE. Previous researches mostly focused on the antidipsotropic effect of isoflavonoids in RPE. The most impressive belongs to the series of studies on daidzin as a selective inhibitor of aldehyde dehydrogenase (ALDH-2) [32-35], and the artificial synthesis analogue with therapeutic potential to reduce ethanol intake and relapse abstinent alcoholics has been developed [36]. On the other hand, puerarin is found to be protective against acute alcoholic 


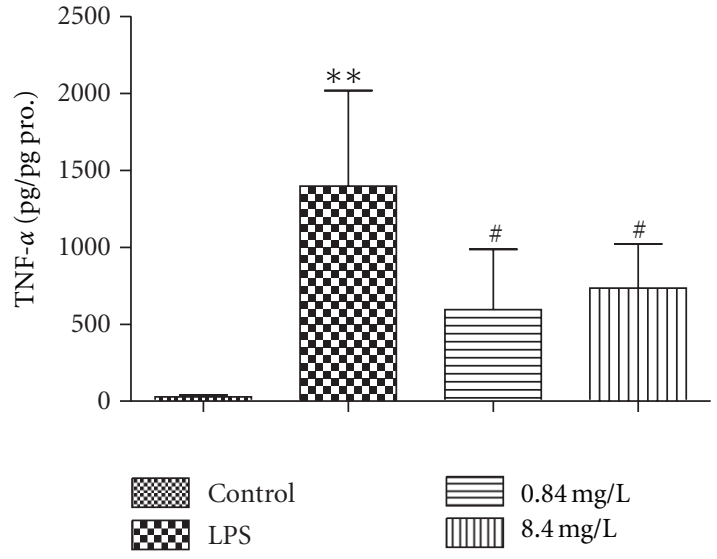

FIgURE 7: Effect of RPE on TNF- $\alpha$ secretion in RAW264.7 cell culture supernatant induced by LPS. RPE inhibited TNF- $\alpha$ secretion induced by LPS in vitro. Values represent the mean \pm SD of three independent experiments. ${ }^{* *} P<0.01$, versus control; ${ }^{*} P<0.05$, versus LPS.

liver injury and alcoholism-related disorders by inhibiting the oxidative stress $[37,38]$ as well as reversed liver fibrosis induced by alcohol compound with carbon tetrachloride by promoting apoptosis of activated hepatic stellate cells (HSCs) [39]. The effect of RPE on chronic alcoholic liver injury and the mechanisms were rarely reported.

In the present study, RPE was observed to inhibit chronic alcoholic liver injury. The histological examination and the biomarkers of liver damage, serum ALT, AST, and hepatic GGT, revealed that RPE alleviated the liver injury induced by Lieber-DeCarli liquid diet. The hepatic TG concentration test suggested that RPE decreased the hepatic lipid deposition induced by chronic alcohol intake, which was also observed in the oil red staining sections.

The role of gut-derived LPS in the pathogenesis of ALD has been widely demonstrated. LPS is the primary endogenous endotoxin of gram-negative bacteria [12]. Longterm ethanol exposure leads to bacterial overgrowth in the gut, disruption of intestinal barrier function, and increase in permeability to endotoxin and bacteria. In response to the endotoxin, KCs produce proinflammatory cytokines, such as TNF- $\alpha$, and cause the surrounding parenchymal cells damage. In the present study, chronic alcohol diet intake caused a significant increase of endotoxin in the portal vein and proinflammatory cytokine, TNF- $\alpha$, secretion in liver tissue. Simultaneously, the protein expression of hepatic CD68 was upregulated remarkably, indicating KCs activation induced by chronic alcohol diet. However, with the administration of RPE, the level of endotoxin in the portal vein did not vary significantly comparing to that in ethanol group, indicating that RPE did not inhibit the endotoxin leakage from intestine induced by alcohol. On the other hand, the TNF- $\alpha$ expression and the KCs activation were all inhibited, which supported RPE blocking proinflammatory cytokine secretion by KCs in chronic liver injury. These results suggested that RPE inhibiting proinflammatory cytokine released by KCs probably did not through decrease in endotoxin leakage from gut induced by alcohol and effects
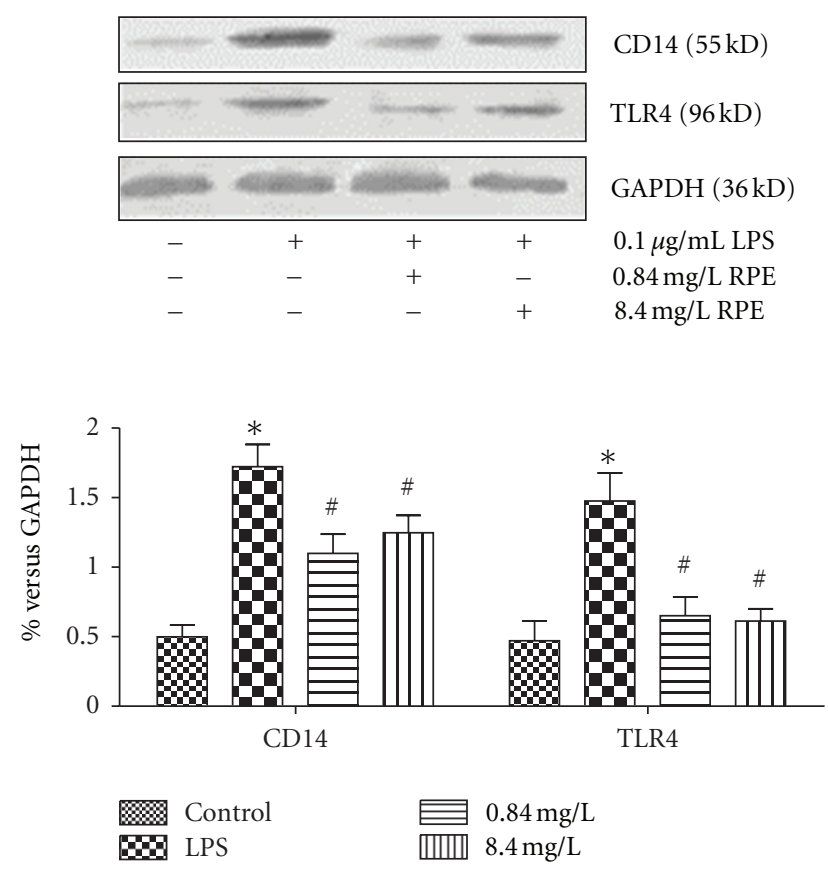

FIGURE 8: Effect of RPE on endotoxin receptors protein expression induced by LPS in vitro. RPE inhibited CD14 and TLR4 protein expression significantly in vitro (western-blot). Values represent the mean \pm SD of three independent experiments. ${ }^{*} P<0.05$, versus control; ${ }^{\#} P<0.05$, versus LPS.

of RPE on endotoxin receptors were then evaluated in vivo and in vitro.

The signal of endotoxin delivery depends on the endotoxin receptors. LBP is produced mostly by hepatocytes and secreted into the bloodstream, where it binds with high affinity to the lipid A portion of LPS and catalyses the transfer of individual LPS molecules to cell surface receptors, such as membrane CD14 (mCD14), forming a monomeric LPSCD14 complex. With LBP presence, the concentration of LPS sufficient for cellular activation is decreased significantly [40]. With the stimulation of proinflammatory cytokines, LBP is constitutively synthesized in hepatocytes [41], which is consistent with the result obtained in the present study, in the rats by in taking alcohol diet from long-term, the protein expression of hepatic LBP was upregulated markedly.

Molecular CD14 anchors on the membrane of peripheral or liver resident microphage (KCs) through glycosylphosphatidylinositol (GPI). LPS-CD14 complex activated cells through TLR4 [42]. It has been clearly established that TLR4 is the specific receptor of LPS from Gram-negative bacteria [42-44]. Signaling through TLR4 requires myeloid differentiated protein-2 (MD-2), a secreted protein that is closely associated with the extracellular domain of TLR4 [45]. In the present research, the protein expression of CD14 and TLR4 in liver tissue was found to be upregulated by chronic alcohol diet intake.

The downstream of TLR4, an endotoxin signal, then occurs through the interleukin-1(IL-1)-receptor pathway, which is MyD88 dependent, or alternatively via a MyD88independent pathway [46]. Ultimately, the endotoxin signal 
TABLE 3: Activity of LDH in RAW264.7 supernatant cultured with different concentrations of RPE.

\begin{tabular}{lc}
\hline Group & LDH (U/pg proteins) \\
\hline Control & $14.61 \pm 3.06$ \\
$84 \mathrm{mg} / \mathrm{L} \mathrm{RPE}$ & $8.69 \pm 4.06^{* *}$ \\
$840 \mathrm{mg} / \mathrm{L} \mathrm{RPE}$ & $11.98 \pm 6.57$ \\
$8.4 \mathrm{~g} / \mathrm{L} \mathrm{RPE}$ & $12.34 \pm 4.26$ \\
\hline
\end{tabular}

${ }^{* *} P<0.01$, versus control.

activates $\mathrm{NF} \kappa \mathrm{B}$ translocation into the nucleus where it induces proinflammatory gene expression, such as TNF- $\alpha$, inducing liver injury. Therefore, the endotoxin receptors are essential for LPS signal delivery and the ultimate proinflammatory gene expression. In the present study, LBP, CD14, and TLR4 expression in liver tissue were all downregulated by RPE treatment comparing to that in ethanol group, which were consistent with its effect on hepatic TNF- $\alpha$. Therefore, data from study in vivo indicated RPE inhibited hepatic TNF- $\alpha$ release induced by chronic alcohol intake probably via downregulating the expression of endotoxin receptors instead of endotoxin leakage from gut.

To observe the effect of RPE on endotoxin receptors and TNF- $\alpha$ expression in macrophage cells induced by LPS directly, the macrophage cell line RAW264.7 was employed in the present study. The results of experiments in vitro revealed that RPE inhibited the TNF- $\alpha$ expression induced by LPS as well as the protein expression of endotoxin receptors, CD14 and TLR4 in RAW264.7 cells, which confirmed the results obtained from study in vivo.

In addition, TLR2 appears to primarily respond to Grampositive bacteria-derived lipoteichoic acid (LTA), peptidoglycan (PGN), and mycobacterial lipoarabinomannan [46]. However, MD-2 enables TLR2 to respond to the LPS and enhances TLR2-mediated responses to both Gram-negative bacteria and their LPS [47]. On the other hand, the cytokines induced by LPS, such as IL- $1 \beta$ or TNF- $\alpha$, upregulate TLR2 mRNA expression in rat hepatocyte in vivo and in vitro [48]. In the present research, the protein expression of TLR2 was found remarkably upregulated in the liver tissue of alcoholdiet raised rats, but not in the LPS stimulated macrophage cell line RAW264.7, which is consistent with our previous studies [27]. Similarly, RPE treatment also downregulated the TLR2 protein expression in rats with chronic alcoholic intake.

\section{Conclusion}

In conclusion, the present study confirmed that RPE mitigated liver damage and lipid deposition induced by chronic alcohol intake as well as TNF- $\alpha$ release, protein expression of endotoxin receptors in vivo and in vitro.

\section{Conflict of Interests}

The authors declare that there is no conflict of interests.

\section{Acknowledgments}

This work was supported by National Natural Science Foundation of China (no. 81001575), Leading Academic Discipline of Hepatology of State Administration of TCM China (NO:2010sh), and the Innovative Research Team in Shanghai Universities, Shanghai Municipal Education Commission.

\section{References}

[1] R. S. O'Shea, S. Dasarathy, and A. J. McCullough, "Alcoholic liver disease," Hepatology, vol. 51, no. 307, p. 328, 2010.

[2] X. Lu, M. Tao, J. Luo, Y. Geng, H. Zhao, and P. Zhao, "Epidemiology of alcohol and liver disease," Zhonghua Gan Zang Bing Za Zhi, vol. 10, no. 6, pp. 467-468, 2002.

[3] I. Bykov, H. Järveläinen, and K. Lindros, "L-carnitine alleviates alcohol-induced liver damage in rats: role of tumour necrosis factor-alpha," Alcohol and Alcoholism, vol. 38, no. 5, pp. 400406, 2003.

[4] M. Fischer, M. You, M. Matsumoto, and D. W. Crabb, "Peroxisome proliferator-activated receptor $\alpha(\operatorname{PPAR} \alpha)$ agonist treatment reverses PPAR $\alpha$ dysfunction and abnormalities in hepatic lipid metabolism in ethanol-fed mice," The Journal of Biological Chemistry, vol. 278, no. 30, pp. 27997-28004, 2003.

[5] A. Galli, J. Pinaire, M. Fischer, R. Dorris, and D. W. Crabb, "The transcriptional and DNA binding activity of peroxisome proliferator-activated receptor $\alpha$ is inhibited by ethanol metabolism. A novel mechanism for the development of ethanol-induced fatty liver," The Journal of Biological Chemistry, vol. 276, no. 1, pp. 68-75, 2001.

[6] C. P. Day and O. F. W. James, "Hepatic steatosis: innocent bystander or guilty party?" Hepatology, vol. 27, no. 6, pp. 1463-1466, 1998.

[7] M. R. Teli, C. P. Day, A. D. Burt, M. K. Bennett, and O. F. W. James, "Determinants of progression to cirrhosis or fibrosis in pure alcoholic fatty liver," The Lancet, vol. 346, no. 8981, pp. 987-990, 1995.

[8] A. P. Bautista, "Neutrophilic infiltration in alcoholic hepatitis," Alcohol, vol. 27, no. 1, pp. 17-21, 2002.

[9] S. W. French, "Alcoholic hepatitis: inflammatory cell-mediated hepatocellular injury," Alcohol, vol. 27, no. 1, pp. 43-46, 2002.

[10] A. M. Diehl, "Liver disease in alcohol abusers: clinical perspective," Alcohol, vol. 27, no. 1, pp. 7-11, 2002.

[11] J. T. Galambos, "Natural history of alcoholic hepatitis. 3. Histological changes," Gastroenterology, vol. 63, no. 6, pp. 1026-1035, 1972.

[12] R. K. Rao, A. Seth, and P. Sheth, "Recent advances in alcoholic liver disease I. Role of intestinal permeability and endotoxemia in alcoholic liver disease," American Journal of Physiology, vol. 286, no. 6, pp. G881-G884, 2004.

[13] D. Seth, P. S. Haber, W. K. Syn, A. M. Diehl, and C. P. Day, "Pathogenesis of alcohol-induced liver disease: classical concepts and recent advances," Journal of Gastroenterology and Hepatology, vol. 26, no. 7, pp. 1089-1105, 2011.

[14] G. L. Su, R. D. Klein, A. Aminlari et al., "Kupffer cell activation by lipopolysaccharide in rats: role for lipopolysaccharide binding protein and toll-like receptor 4," Hepatology, vol. 31, no. 4, pp. 932-936, 2000.

[15] C. A. Bradham, J. Plümpe, M. P. Manns, D. A. Brenner, and C. Trautwein, "Mechanisms of hepatic toxicity. I. TNF-induced liver injury," American Journal of Physiology, vol. 275, no. 3, part 1, pp. G387-G392, 1998. 
[16] W. M. Keung and B. L. Vallee, "Daidzin and daidzein suppress free-choice ethanol intake by Syrian golden hamsters," Proceedings of the National Academy of Sciences of the United States of America, vol. 90, no. 21, pp. 10008-10012, 1993.

[17] E. Benlhabib, J. I. Baker, D. E. Keyler, and A. K. Singh, "Kudzu root extract suppresses voluntary alcohol intake and alcohol withdrawal symptoms in $\mathrm{P}$ rats receiving free access to water and alcohol," Journal of Medicinal Food, vol. 7, no. 2, pp. 168 179, 2004.

[18] R. C. Lin and T. K. Li, "Effects of isoflavones on alcohol pharmacokinetics and alcohol-drinking behavior in rats," American Journal of Clinical Nutrition, vol. 68, no. 6, pp. 1512S-1515S, 1998.

[19] E. Benlhabib, J. I. Baker, D. E. Keyler, and A. K. Singh, "Effects of purified puerarin on voluntary alcohol intake and alcohol withdrawal symptoms in $\mathrm{P}$ rats receiving free access to water and alcohol," Journal of Medicinal Food, vol. 7, no. 2, pp. 180 186, 2004.

[20] R. C. Lin, S. Guthrie, C. Y. Xie et al., "Isoflavonoid compounds extracted from Pueraria lobata suppress alcohol preference in a pharmacogenetic rat model of alcoholism," Alcoholism, vol. 20, no. 4, pp. 659-663, 1996.

[21] A. K. Singh, Y. Jiang, E. Benlhabib, and S. Gupta, "Herbal mixtures consisting of puerarin and either polyenylphosphatidylcholine or curcumin provide comprehensive protection against alcohol-related disorders in $\mathrm{P}$ rats receiving free choice water and 15\% ethanol in pure water," Journal of Medicinal Food, vol. 10, no. 3, pp. 526-542, 2007.

[22] D. H. Overstreet, J. E. Kralic, A. L. Morrow, Z. Z. Ma, Y. W. Zhang, and D. Y. W. Lee, "NPI-031G (puerarin) reduces anxiogenic effects of alcohol withdrawal or benzodiazepine inverse or 5- $\mathrm{HT}_{2 \mathrm{C}}$ agonists," Pharmacology Biochemistry and Behavior, vol. 75, no. 3, pp. 619-625, 2003.

[23] G. M. Heyman, W. M. Keung, and B. L. Vallee, "Daidzin decreases ethanol consumption in rats," Alcoholism, vol. 20, no. 6, pp. 1083-1087, 1996.

[24] M. K. Lee, S. Y. Cho, J. Y. Jang et al., "Effects of puerariae flos and puerariae radix extracts on antioxidant enzymes in ethanol-treated rats," The American Journal of Chinese Medicine, vol. 29, no. 2, pp. 343-354, 2001.

[25] C. S. Lieber and L. M. DeCarli, "The feeding of alcohol in liquid diets: two decades of applications and 1982 update," Alcoholism, vol. 6, no. 4, pp. 523-531, 1982.

[26] Z. H. Fang, J. W. Cui, J. M. Cao, J. H. Peng, Q. Feng, and Y. Y. Hu, "Preparation of Lieber-DeCarli liquid diet induced alcoholic hepatic injury model in rats," Zhong Xi Yi Jie He Xue Bao, vol. 4, no. 6, pp. 596-600, 2006.

[27] J. H. Peng, Y. Y. Hu, Y. Cheng et al., "Effect of JIANPI HUOXUE decoction on inflammatory cytokine secretion pathway in rat liver with lipopolysaccharide challenge," World Journal of Gastroenterology, vol. 14, no. 12, pp. 1851-1857, 2008.

[28] J. C. Lambert, Z. Zhou, L. Wang, Z. Song, C. J. McClain, and Y. J. Kang, "Prevention of alterations in intestinal permeability is involved in zinc inhibition of acute ethanol-induced liver damage in mice," Journal of Pharmacology and Experimental Therapeutics, vol. 305, no. 3, pp. 880-886, 2003.

[29] J. H. Peng, Y. Y. Hu, Q. Feng et al., "Effect of Jianpi Huoxue decoction-containing serum on tumor necrosis factor- $\alpha$ secretion and gene expression of endotoxin receptors in RAW264.7 cells induced by lipopolysaccharide," Chinese Journal of Integrative Medicine, vol. 15, no. 3, pp. 198-203, 2009.

[30] S. S. Rabinowitz and S. Gordon, "Macrosialin, a macrophagerestricted membrane sialoprotein differentially glycosylated in response to inflammatory stimuli," Journal of Experimental Medicine, vol. 174, no. 4, pp. 827-836, 1991.

[31] G. L. Su, P. D. Freeswick, D. A. Geller et al., "Molecular cloning, characterization, and tissue distribution of rat lipopolysaccharide binding protein: evidence for extrahepatic expression," The Journal of Immunology, vol. 153, no. 2, pp. 743-752, 1994.

[32] W. M. Keung, A. A. Klyosov, and B. L. Vallee, "Daidzin inhibits mitochondrial aldehyde dehydrogenase and suppresses ethanol intake of Syrian golden hamsters," Proceedings of the National Academy of Sciences of the United States of America, vol. 94, no. 5, pp. 1675-1679, 1997.

[33] W. M. Keung and B. L. Vallee, "Daidzin and its antidipsotropic analogs inhibit serotonin and dopamine metabolism in isolated mitochondria," Proceedings of the National Academy of Sciences of the United States of America, vol. 95, no. 5, pp. 21982203, 1998.

[34] N. Rooke, D. J. Li, J. Li, and W. M. Keung, "The mitochondrial monoamine oxidase-aldehyde dehydrogenase pathway: a potential site of action of daidzin," Journal of Medicinal Chemistry, vol. 43, no. 22, pp. 4169-4179, 2000.

[35] W. M. Keung, "Biogenic aldehyde(s) derived from the action of monoamine oxidase may mediate the antidipsotropic effect of daidzin," Chemico-Biological Interactions, vol. 130-132, pp. 919-930, 2001.

[36] M. P. Arolfo, D. H. Overstreet, L. Yao et al., "Suppression of heavy drinking and alcohol seeking by a selective ALDH-2 inhibitor," Alcoholism, vol. 33, no. 11, pp. 1935-1944, 2009.

[37] M. Zhao, Y. Q. Du, L. Yuan, and N. N. Wang, "Protective effect of puerarin on acute alcoholic liver injury," The American Journal of Chinese Medicine, vol. 38, no. 2, pp. 241-249, 2010.

[38] Z. Zhang, S. Li, J. Jiang, P. Yu, J. Liang, and Y. Wang, "Preventive effects of Flos Perariae (Gehua) water extract and its active ingredient puerarin in rodent alcoholism models," Chinese Medicine, vol. 5, article 36, 2010.

[39] S. Zhang, G. Ji, and J. Liu, "Reversal of chemical-induced liver fibrosis in Wistar rats by puerarin," The Journal of Nutritional Biochemistry, vol. 17, no. 7, pp. 485-491, 2006.

[40] R. R. Schumann, "Function of lipopolysaccharide (LPS)binding protein (LBP) and CD14, the receptor for LPS/LBP complexes: a short review," Research in Immunology, vol. 143, no. 1, pp. 11-15, 1992.

[41] C. Elsing, S. Ernst, N. Kayali, W. Stremmel, and S. Harenberg, "Lipopolysaccharide binding protein, interleukin-6 and Creactive protein in acute gastrointestinal infections: value as biomarkers to reduce unnecessary antibiotic therapy," Infection, vol. 39, no. 4, pp. 327-331, 2011.

[42] K. Triantafilou, M. Triantafilou, and R. L. Dedrick, "Interactions of bacterial lipopolysaccharide and peptidoglycan with a $70 \mathrm{kDa}$ and an $80 \mathrm{kDa}$ protein on the cell surface of $\mathrm{CD} 14^{+}$ and CD14- cells," Human Immunology, vol. 62, no. 1, pp. 5063, 2001.

[43] G. L. Su, "Lipopolysaccharides in liver injury: molecular mechanisms of Kupffer cell activation," American Journal of Physiology, vol. 283, no. 2, pp. G256-G265, 2002.

[44] T. Uesugi, M. Froh, G. E. Arteel, B. U. Bradford, and R. G. Thurman, "Toll-like receptor 4 is involved in the mechanism of early alcohol-induced liver injury in mice," Hepatology, vol. 34, no. 1, pp. 101-108, 2001.

[45] R. Shimazu, S. Akashi, H. Ogata et al., "MD-2, a molecule that confers lipopolysaccharide responsiveness on toll-like receptor 4," Journal of Experimental Medicine, vol. 189, no. 11, pp. 1777-1782, 1999. 
[46] S. Akira, K. Takeda, and T. Kaisho, "Toll-like receptors: critical proteins linking innate and acquired immunity," Nature Immunology, vol. 2, no. 8, pp. 675-680, 2001.

[47] R. Dziarski, Q. Wang, K. Miyake, C. J. Kirschning, and D. Gupta, "MD-2 enables toll-like receptor 2 (TLR2)-mediated responses to lipopolysaccharide and enhances TLR2-mediated responses to Gram-positive and Gram-negative bacteria and their cell wall components," The Journal of Immunology, vol. 166, no. 3, pp. 1938-1944, 2001.

[48] S. Liu, A. N. Salyapongse, D. A. Geller, Y. Vodovotz, and T. R. Billiar, "Hepatocyte toll-like receptor 2 expression in vivo and in vitro: role of cytokines in induction of rat TLR2 gene expression by lipopolysaccharide," Shock, vol. 14, no. 3, pp. 361-365, 2000. 


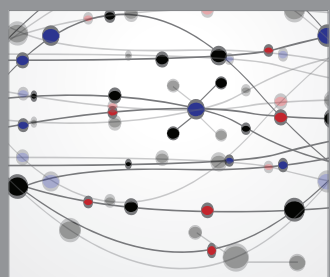

The Scientific World Journal
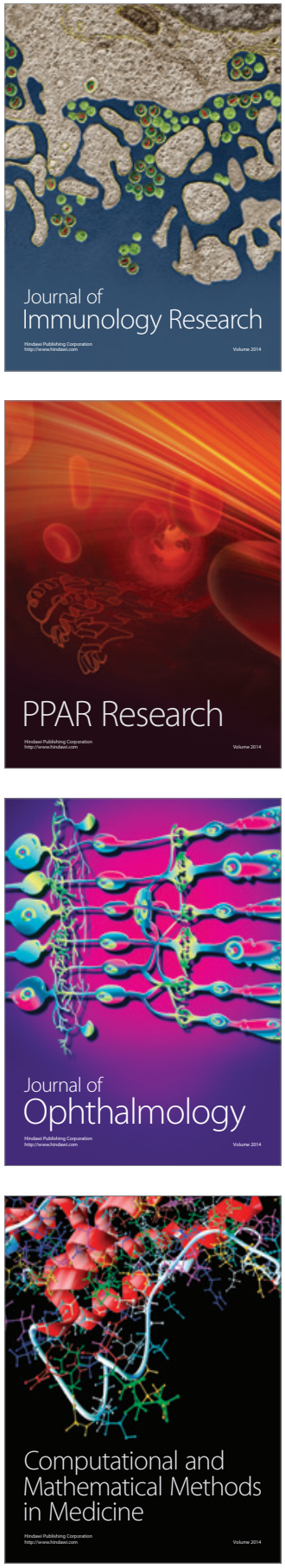

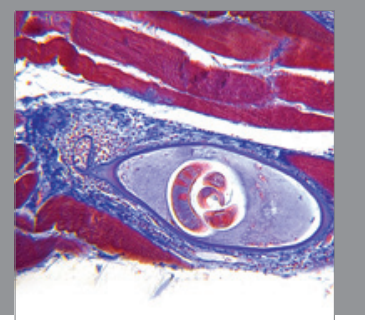

Gastroenterology

Research and Practice
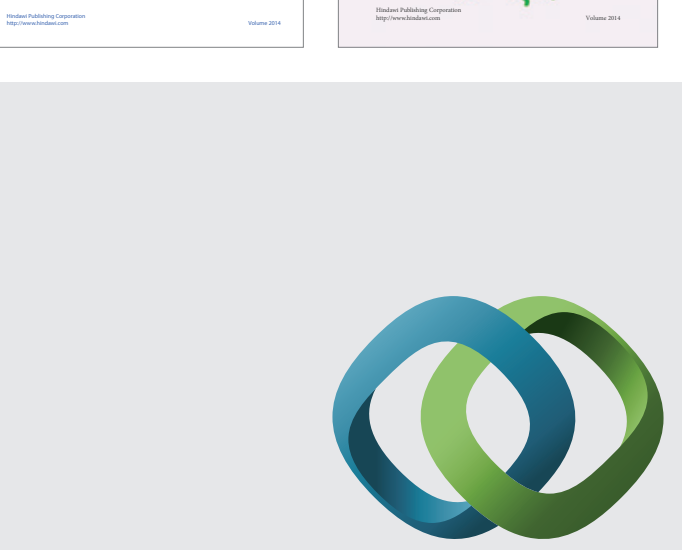

\section{Hindawi}

Submit your manuscripts at

http://www.hindawi.com
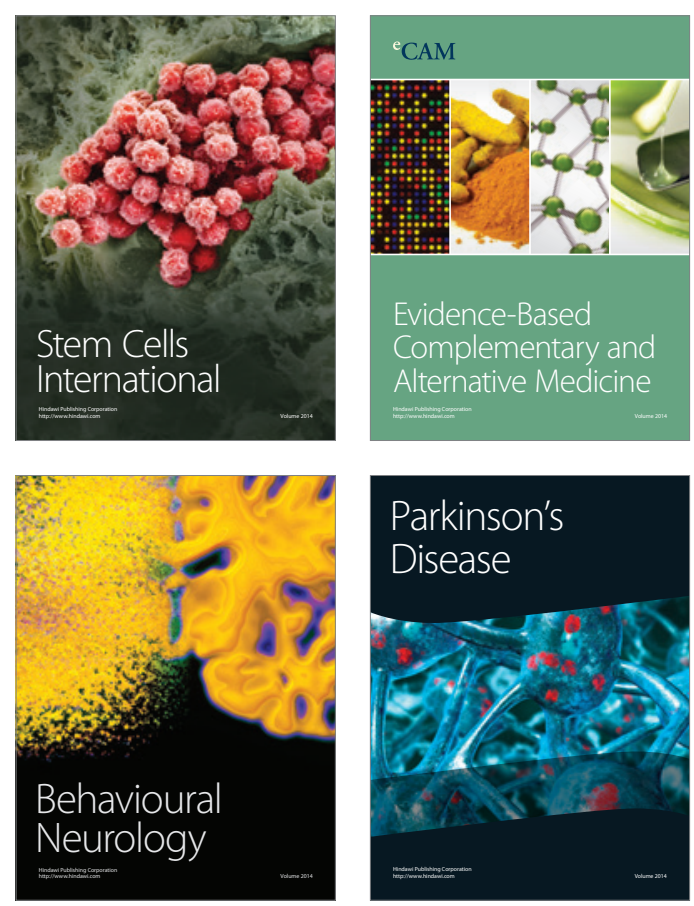

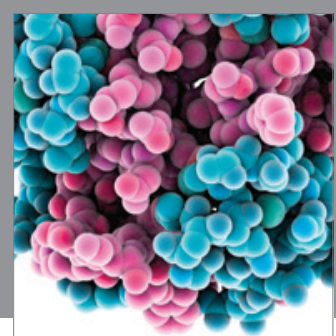

Journal of
Diabetes Research

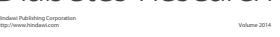

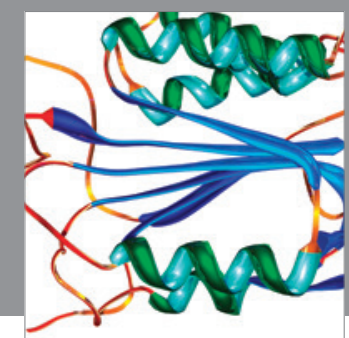

Disease Markers
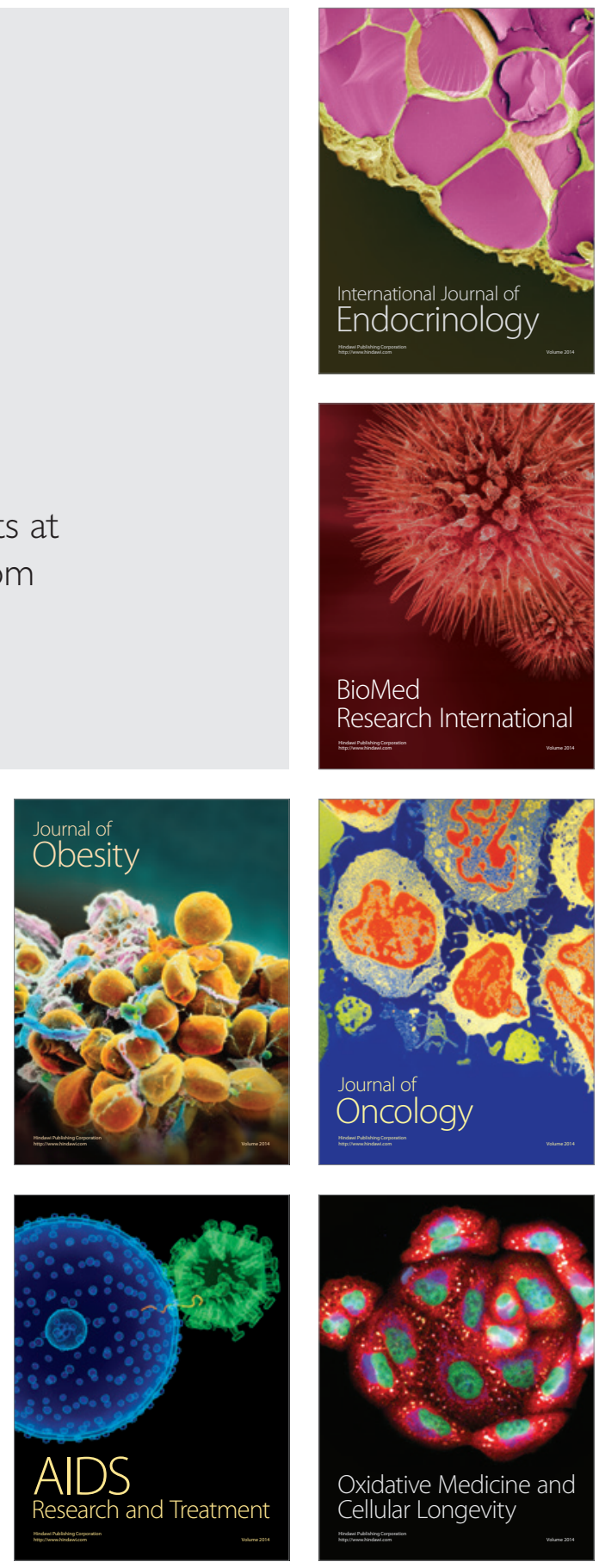